\title{
An assessment of Project-Based Learning towards Applied Health Informatics Teaching in an Undergraduate Class
}

\author{
Lidiany C. Santos ${ }^{1,2}$, Danilo F. Neves ${ }^{1,3}$, Fabrício dos Santos Menezes ${ }^{2,4}$ \\ ${ }^{1}$ Serviço de Tecnologia da Informação - UFS \\ Lagarto - SE - Brasil \\ ${ }^{2}$ Departamento de Educação em Saúde - Universidade Federal de Sergipe (UFS) \\ Lagarto - SE - Brasil \\ ${ }^{3}$ Programa de Pós-graduação em Ciência da Computação - UFS \\ São Cristóvão - SE - Brasil \\ ${ }^{4}$ Programa de Pós-graduação em Epidemiologia - Faculdade de Saúde Pública \\ Universidade de São Paulo - São Paulo - SP - Brasil \\ \{lidianycs, danilo.neves\}@ufs.br, fabriciomenezes@msn.com
}

\begin{abstract}
This study aims to report and evaluate teaching based on ProjectBased Learning towards an undergraduate subject of Applied Health Informatics. As an evaluation method, the development of mobile health applications was proposed. The research was conducted in a class with 21 students, who were evaluated qualitatively by two surveys. The students reported a positive impact of the discipline on their training and improvement in computational thinking abilities. Overall, the students created six m-health applications, and they achieved a new technology perception. Moreover, 15 students (71.4\%) said to be more motivated to learn new technologies and 16 (76.2\%) reported to be able to develop new applications.
\end{abstract}

\section{Introduction}

The health area has benefiting from advances in information and communication technologies (ICT). However, despite advances in applied health informatics, Brazil is still working on its healthcare sector computerization. The Ministry of Health has defined as one of its priority objectives the strategic construction of a health information and informatics policy. In this way, the National Health Information and Informatics Policy (PNIIS) of the Unified Health System (SUS) was created to meet the demands of computerization of the sector and had its latest version published in 2016. This policy aims to computerize processes in the health area, both in the individual care and in collective health actions, increasing the efficiency and quality of services ${ }^{1}$.

The need to teaching health informatics in undergraduate courses and also in permanent education programs is foreseen in this policy, establishing relationships between ICTs and professional health practice. Thus, it aims to contribute to the improvement of the learning process allowing the students to idealize the application of

\footnotetext{
${ }^{1}$ http://bvsms.saude.gov.br/bvs/saudelegis/gm/2015/prt05892005 2015.html
} 
IX Congresso Brasileiro de Informática na Educação (CBIE 2020)

Anais do XXXI Simpósio Brasileiro de Informática na Educação (SBIE 2020)

the technologies in their professional reality [Cardoso et al 2008]. However, despite the growing importance for the area, the provision of health discipline informatics classes in undergraduate courses is still short, finding difficulties due to the lack of trained professionals and inadequate infrastructure [Santos et al 2017].

Health education has transformed, both in the technological and pedagogical fields, aiming to stimulate students' autonomy, participation, and proactivity by the adoption of active learning methodologies [Mitre et al 2008]. This paper reports the experience and possibilities of teaching practice in health informatics, by the use of a Project-Based Learning (PBL) approach. PBL is a model that encourages students to solve real problems, taking responsibility for their own learning and working collaboratively with other students, enhancing their investigation and problem-solving skills [Bilgin et al 2015]. The research was motivated by the opportunity for students' educational and professional enrichment [Pereira et al 2017] and to reevaluate the adoption of PBL in context of health informatics, improving results of previous works [Santos 2018, Santos 2019], once this is still an educational area under development in Brazil, which lacks further studies and experiments.

Thus, in order to evaluate the PBL approach in the context of health informatics teaching, we carried out an exploratory research with students of an elective class in Applied Health Informatics, offered by the Department of Health Education at the Federal University of Sergipe.

The participants were encouraged to think about real projects, identify opportunities, research and design applications in their areas of study. The course introduced basic concepts of programming and development on the perspective of App Inventor 2 mobile application creation platform.

The main contribution of this article is to present the qualitative results of the method's evaluation by the students. Further results can help instructors and teachers of this area with teaching planning in order to integrate PBL into their classes, as well as a guide to developing instructional units. We also hope that the discussion can foster the health informatics education.

This article discusses in section 1 a brief background on applied health informatics, PBL approach and the goals of this paper. The following sections present the proposed methodology, with some information about the adopted teaching plan, the pretest, and posttest surveys, illustrating them.

Further, section three presents the results obtained with the qualitative evaluation, the surveys, and the apps developed by the students. Finally, conclusions are presented.

\section{Methodology}

The research was developed on a qualitative approach under an exploratory method. The work was conducted in an Applied Health Informatics discipline; an elective 60 hours course for undergraduate students. Twenty-one students from Pharmacy, Speech Therapy, Physiotherapy and Nutrition courses participated in the study. The teacher who supervised the projects of the students has a Bachelor in Computer Engineering and a

\footnotetext{
${ }^{2}$ http://ai2.appinventor.mit.edu
} 
IX Congresso Brasileiro de Informática na Educação (CBIE 2020)

Anais do XXXI Simpósio Brasileiro de Informática na Educação (SBIE 2020)

Masters in Computer Science, working in Education, Software Engineering, and Health Informatics area.

Based on a literature review, Kokotsaki et al. [2016] made key recommendations considered essential for the successful adoption of a PBL approach. Following these recommendations, the whole teaching plan of the discipline was set up. The flowchart based on the pedagogical plan of the discipline is presented in Fig. 1, it was also used in the previous semester [Santos 2019].

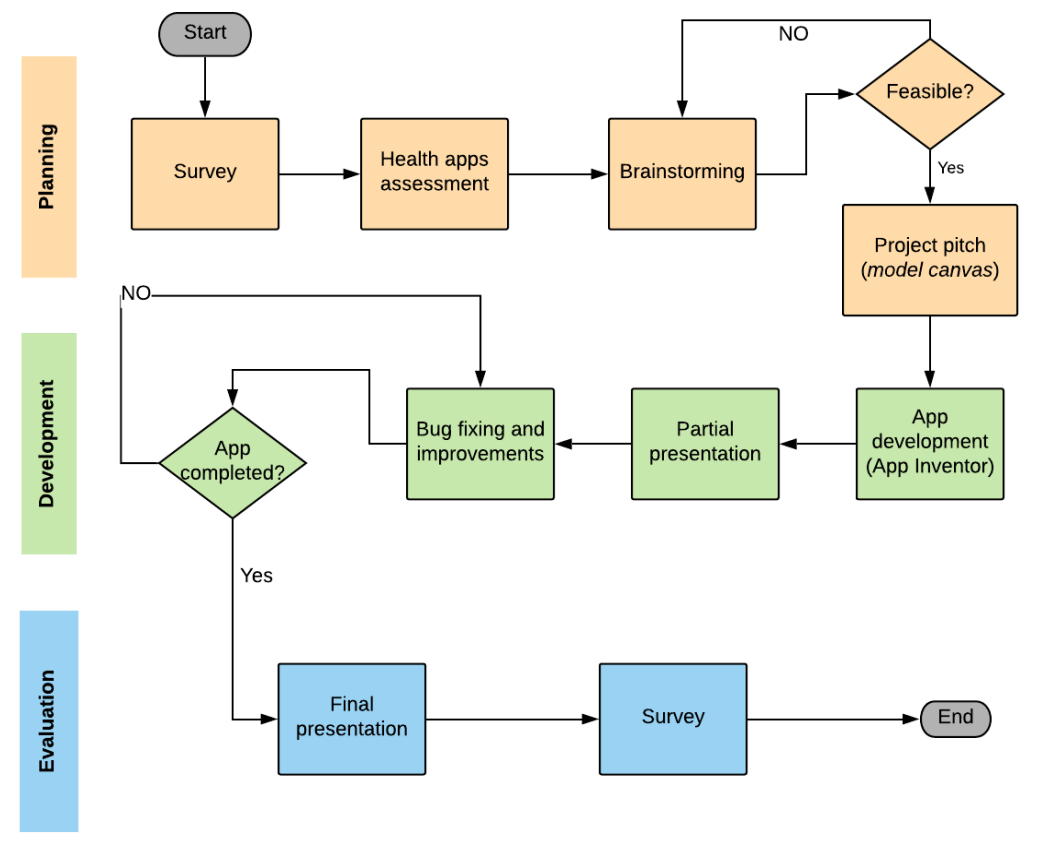

Fig. 1. Flowchart of activities performed in the course.

The development of a mobile application was established as a project plan since PBL needs the construction of an end product, a 'concrete artifact' [Helle et al. 2006]. The project was built with App Inventor, as there were students with little knowledge of programming, and it supports students to develop computational practices more efficiently. App Inventor is a platform based on graphic logical blocks [Wolber et al. 2014]. The students were challenged to carry out the projects concerned on their own, researching and applying their knowledge. Under the teacher supervision, which had the role to motivate and organize the activities, they were guided and supported. For project building and alignment to the PBL model, the classes followed a division based on 3 phases: Planning, Development, and Evaluation.

\subsection{Planning}

At this stage, the students were instructed to search for health applications and evaluate a list of applications suggested by the teacher. After, the students were sorted into seven groups with three members each and started a Brainstorming session to define the project. The Brainstorming process encouraged students to exercise group communication and creative capacity [Baron et al. 1998]. In that way, it helped students to develop a sense of ownership and control over their learning [Kokotsaki et al. 2016]. The viability and resources needed for development were assessed with defined project goals. If the projects were not feasible, the students would perform a new 
IX Congresso Brasileiro de Informática na Educação (CBIE 2020)

Anais do XXXI Simpósio Brasileiro de Informática na Educação (SBIE 2020)

Brainstorming. The cycle repeated until the students to achieve a project compatible with their reality, knowledge, and skills.

The projects were presented to the class with the help of the Project Model Canvas (PMC), specifying the target audience, objectives, and benefits. PMC is based on Business Model Generation (BMG), but it uses a project-specific orientation [Finocchio 2013, Campos 2016]. It is a visual scheme that enables project management in a fast and straightforward way, eliminating documents and bureaucracy, which allows changes when necessary. Each team was invited to create a project canvas. The method was explained to the students, and materials used for constructing the models were provided: paperboard, post-its, pens, and pilots. After creating the canvas, the students made a pitch showing their planning to the rest of the class.

\subsection{Development}

At this stage, the students start building the applications. Alternating between practice and theory, programming lessons on the App Inventor platform were taught, besides lessons in algorithms and prototyping at the same time as the application design was developed. As one of the six recommendations from Kokotsaki et al [2016], regular support on the use of technology was provided by the teacher, balancing didactic instruction with independent inquiry method work. After the conceptual classes have been completed and the prototypes finished, the teams made a pitch to present their projects. In each presentation, the other groups were encouraged to criticize and offer suggestions, thereby the assessment emphasized on reflection, self, and peer evaluation. Thereafter, under teacher supervision, the students began a cycle of maintenance and improvement until the project deadline.

\subsection{Evaluation}

In the final class, the teams presented their applications. They demonstrated the application running, discussed the initial planning, and the changes realized to deliver the final product. Once again, all the students were invited to evaluate and criticize the projects presented. At an exploratory level, two Surveys were applied in the course of the discipline. Both were developed on a Likert type scale with the addition of subjective questions. The pretest Survey is described in Fig. 2.

\begin{tabular}{|c|c|c|}
\hline \multicolumn{3}{|c|}{ Pretest Survey } \\
\hline \multicolumn{2}{|l|}{ 1. What is your age? } & \\
\hline \multirow{2}{*}{$\begin{array}{l}\text { 2. How long do you use your } \\
\text { smartphone throughout the day? }\end{array}$} & \multicolumn{2}{|c|}{ Less than 2 hours $\square$ Between 2 and 5 hours } \\
\hline & \multicolumn{2}{|c|}{$\begin{array}{c}\square \text { Between } 5 \text { and } 10 \text { hours } \square \text { More than } 10 \text { hours } \\
\square \text { I don't own a smartphone } \square\end{array}$} \\
\hline \multicolumn{2}{|c|}{$\begin{array}{l}\text { 3. Do you usually use your smartphone to study and perform } \\
\text { activities related to the course? }\end{array}$} & Never $\square \square \square \square \square$ Always \\
\hline \multicolumn{2}{|c|}{$\begin{array}{l}\text { 4. Do you know or use tablet / smartphone apps related to } \\
\text { your course / study area? }\end{array}$} & Yes $\square$ No $\square$ \\
\hline \multicolumn{2}{|c|}{ 5. If so, please tell which applications you know or use. } & \\
\hline \multicolumn{2}{|c|}{$\begin{array}{l}\text { 6. Have you thought about developing a smartphone / tablet } \\
\text { application? }\end{array}$} & Yes $\square$ No $\square$ \\
\hline \multicolumn{2}{|c|}{$\begin{array}{l}\text { 7. If so, what motivated you to think about developing an } \\
\text { application? What is its purpose? }\end{array}$} & \\
\hline \multicolumn{2}{|c|}{ 8. How would you rate your computer literacy? } & None $\square \square \square \square \square$ Advanced \\
\hline \multicolumn{2}{|c|}{ 9. How would you rate your programming knowledge? } & None $\square \square \square \square \square$ Advanced \\
\hline \multicolumn{2}{|c|}{ 10. Have you ever been interested in learning to program? } & Yes $\square$ No $\square$ \\
\hline \multicolumn{2}{|c|}{ 11. What do you expect to learn in this course? } & \\
\hline
\end{tabular}

Fig. 2. Survey applied in the first class. 
The first survey (pretest) was applied at the beginning of the course and aimed to know students' perceptions regarding the computer field, the use of technology, computer knowledge and interest in software development. The posttest Survey was answered at the end of the course to verify the concepts learned, difficulties, and changes in the perception about the area and the PBL methodology used. The Posttest Survey is presented in Fig. 3. Previously, we informed the students about the research purpose and on the anonymous course evaluations.

\begin{tabular}{|l|l|}
\hline \multicolumn{3}{|c|}{ Posttest Survey } \\
\hline 1. How would you rate your computer literacy? & None $\square \square \square \square \square$ Advanced \\
\hline $\begin{array}{l}\text { 2. How would you rate your knowledge about program } \\
\text { (application) development? }\end{array}$ & None $\square \square \square \square \square$ Advanced \\
\hline 3. How hard do you think application development is? & Very difficult $\square \square \square \square \square$ Easy \\
\hline $\begin{array}{l}\text { 4. How difficult do you consider the App Inventor tool in } \\
\text { application development? }\end{array}$ & Very difficult $\square \square \square \square \square$ Easy \\
\hline $\begin{array}{l}\text { 5. Do the skills acquired throughout the course } \\
\text { allow you to develop an application? }\end{array}$ & Strongly disagree $\square \square \square \square \square$ Strongly agree \\
\hline 6. Are you interested in keep on developing applications? & Yes $\square$ No $\square$ \\
\hline $\begin{array}{l}\text { 7. Did you have difficulties in creating applications? If so, } \\
\text { which ones? }\end{array}$ \\
\hline 8. What concepts were learned in the discipline specifically? & \\
\hline 9. Did you feel motivated during the discipline? & Strongly disagree $\square \square \square \square$ Strongly agree \\
\hline $\begin{array}{l}\text { 10. Has the course contributed positively by } \\
\text { adding value to your training? }\end{array}$ & Strongly disagree $\square \square \square \square \square$ Strongly agree \\
\hline $\begin{array}{l}\text { 11. Was the methodology used in the course } \\
\text { adequate? }\end{array}$ & Strongly disagree $\square \square \square \square \square$ Strongly agree \\
\hline $\begin{array}{l}\text { 12. Did the course contribute to your academic } \\
\text { and professional training? }\end{array}$ & Strongly disagree $\square \square \square \square \square$ Strongly agree \\
\hline 13. Are the concepts learned throughout the course of great importance to the market? \\
\hline 14. Would you recommend the course to other colleagues? \\
\hline $\begin{array}{l}\text { 15. Present your opinion about the course and the methodology } \\
\text { used (suggestions for improvement, personal perception, } \\
\text { environment, contributions, positives and negatives). }\end{array}$ \\
\hline
\end{tabular}

Fig. 3 - Survey applied at the end of the course.

\section{Results}

The data collected were obtained from the evaluation of research and the projects developed in the classroom. The analysis of the data made it possible to draw a profile of the students and evaluate the change of perception regarding technology and the efficiency of the PBL methodology.

The group was composed of 21 students, with a large female majority (19 students), aged between 18 and 25 years, coursing Pharmacy (6 students), Physiotherapy (4 students), Speech Therapy (9 students) and Nutrition (2 students). More than half of these students are frequent users of mobile technology, $40 \%$ reported using the devices between 5 to 10 hours a day and $41 \%$ reported using smartphones for academic purposes. In relation to profile, students reported a low technical knowledge in informatics. Overall, 96\% of the participants had moderate knowledge and basic knowledge. Furthermore, the students' self-perception on programming skills were insufficient for $67 \%$ of the participants (Fig. 4).A reflection of the inexperience in computing and programming is revealed by the answers about creating applications, once $85 \%$ of the students described a no prior interest in developing apps. However, half 
IX Congresso Brasileiro de Informática na Educação (CBIE 2020)

Anais do XXXI Simpósio Brasileiro de Informática na Educação (SBIE 2020)

of the students expressed interest in programming learning $(50 \%)$, which indicates a possible engagement of the class with the proposed methodology.

Throughout the course, students demonstrated their commitment to app development, leading field and library research using the university laboratories. As a result, they developed six applications, created illustrations and photographs. In Fig. 5, three of then six applications developed by the class are presented. From left to right: Med DEP is an app to evaluate the drug dependency profile; the CigaretteTD

Informatics Skills

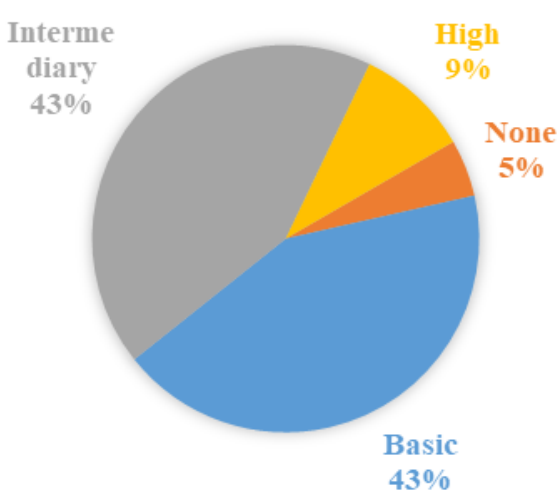

Programming Skills

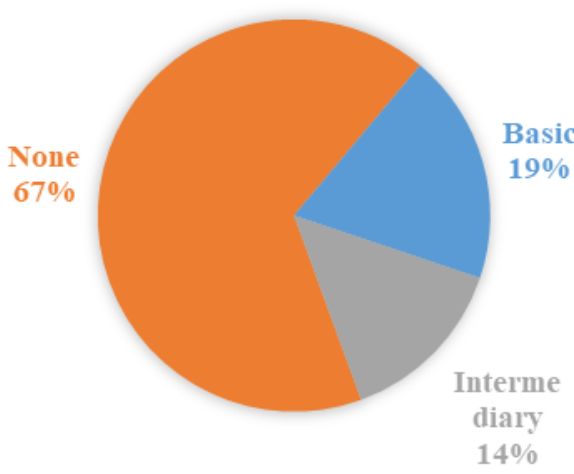

(CigarroTD) aims to evaluate the type of smoking dependence; HelpTuts is a didactic application intended to assist students on saving notes of tutorial classes.

Fig 4. Student's self-assessment of programming and informatics skills.

Fig. 6 presents the other three apps developed by the class. Urinary Incontinence (UI) is an application to evaluate the impact of urinary incontinence on quality of life; QuizAD is an application to assess depression and anxiety levels and to enable early detection of depression; Chewing Physiology is an application designed for aiding health students with content about the chewing physiology.
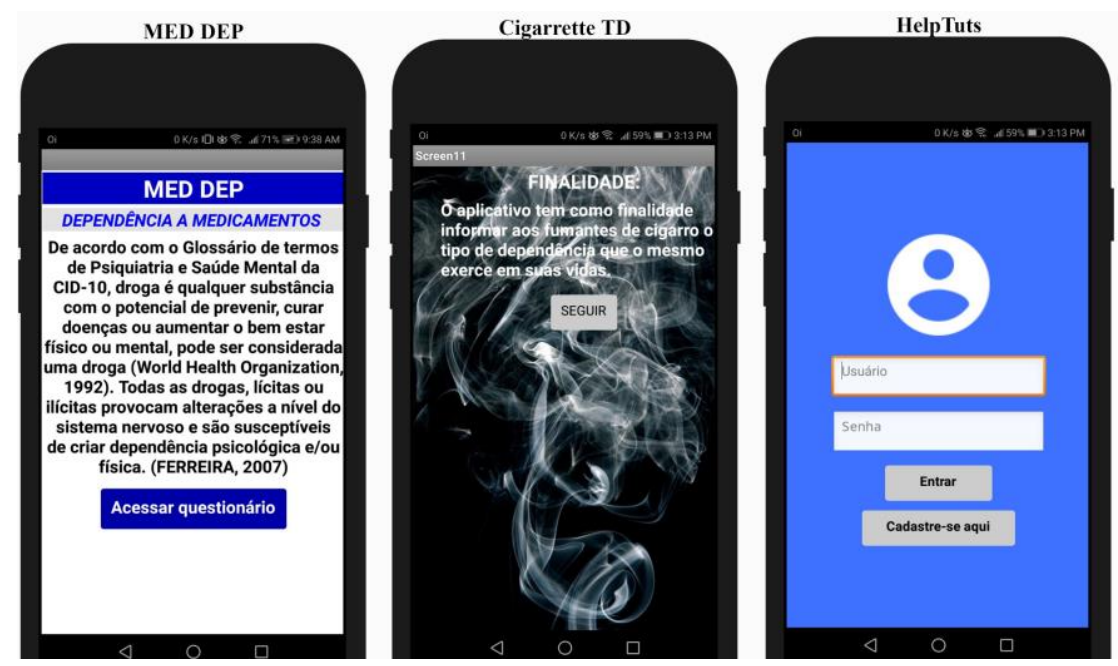

Fig. 5. Apps Med Dep, CigaretteTD (CigarroTD) and HelpTuts.

All applications were developed on the App Inventor platform, which facilitated the development (Fig. 7). Only one group did not submit the final project of their app. This team intended to develop an application to provide information about adverse drug reactions, but the members missed some theoretical and consulting classes, delaying the 
IX Congresso Brasileiro de Informática na Educação (CBIE 2020)

Anais do XXXI Simpósio Brasileiro de Informática na Educação (SBIE 2020)

project schedule and consequently failed to develop the initially planned app. A physiotherapy student dropped out of her course and therefore the discipline. Thus, among the 21 enrolled students, only one failed the course.
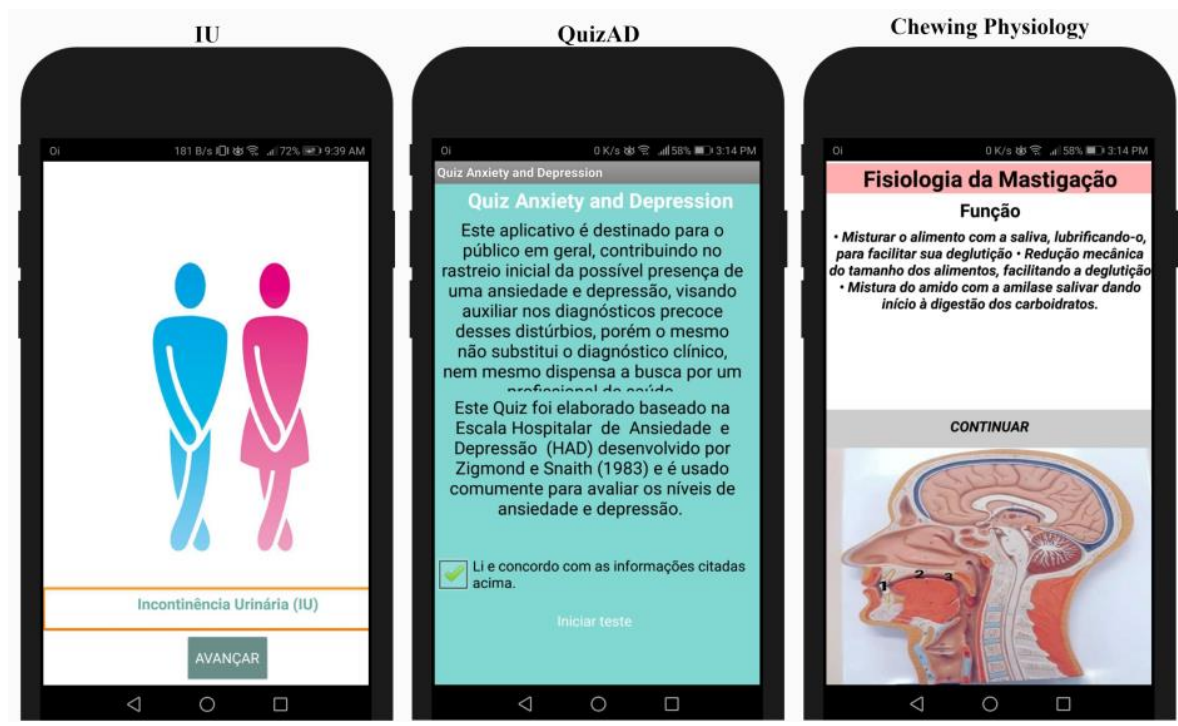

Fig. 6. Applications Urinary Incontinence (UI), QuizAD and Chewing Physiology.

Despite difficulties with advanced content, 15 of the 20 students were interested in learning new technologies and felt motivated to develop and present an application (Fig. 8). By self-assessing, 15 of these students considered themselves suitable to create new applications and still confirmed their interest in continuing to develop (75\%).

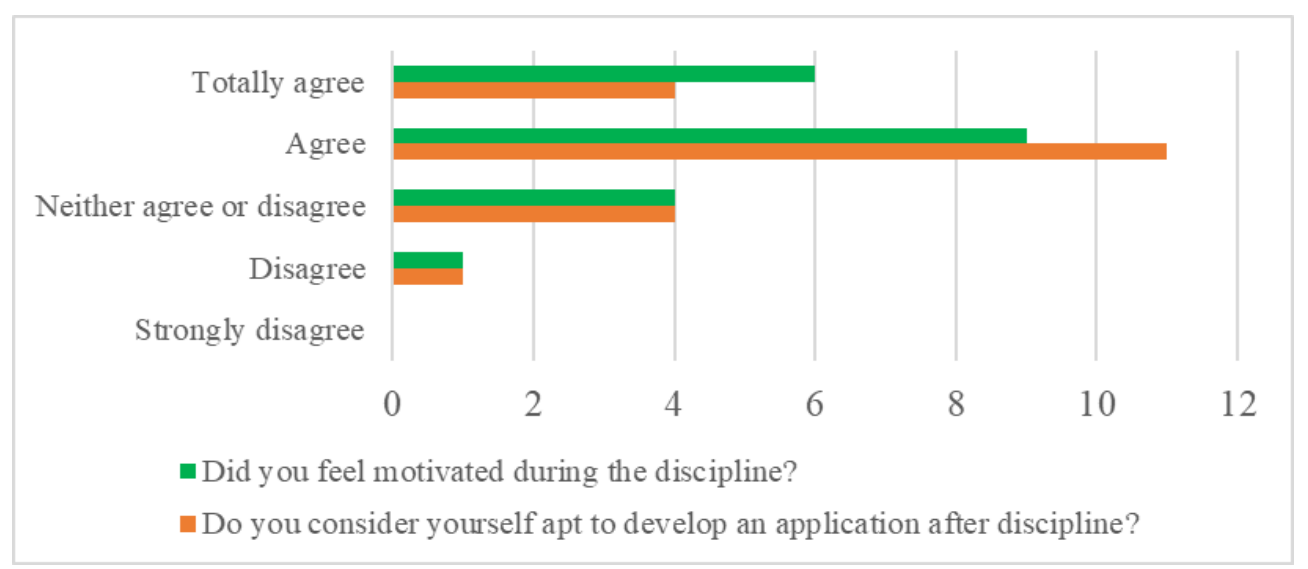

Fig. 7. Perception of difficulty in using App Inventor and creating applications.

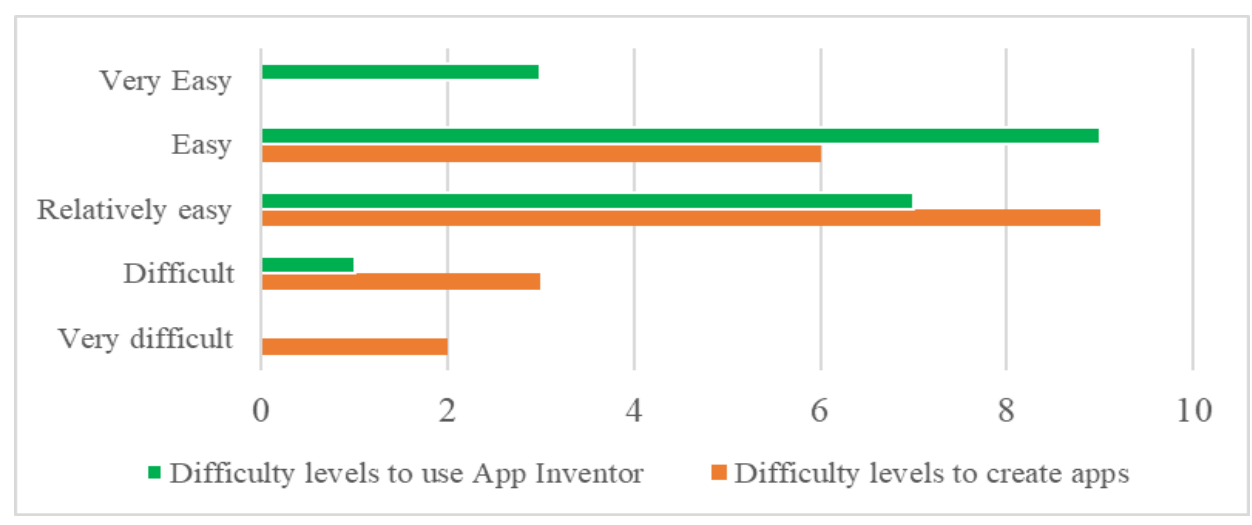

Fig. 8. Self-assessing on motivation and interest in developing new applications 
IX Congresso Brasileiro de Informática na Educação (CBIE 2020)

Anais do XXXI Simpósio Brasileiro de Informática na Educação (SBIE 2020)

In addition to the app release and presentation, the groups created a one-page report describing the project, the application, and references used. In the last class, the students were enthusiastic about presenting their projects and showing the results of their work. When the students were asked if the methodology had been adequate, $80 \%$ agreed, 20\% were neutral, and none disagreed (Fig. 9). The majority of the students believed the discipline contributed positively to their education $(90 \%)$, and some expressed their interest in improving their projects and present them to the community.
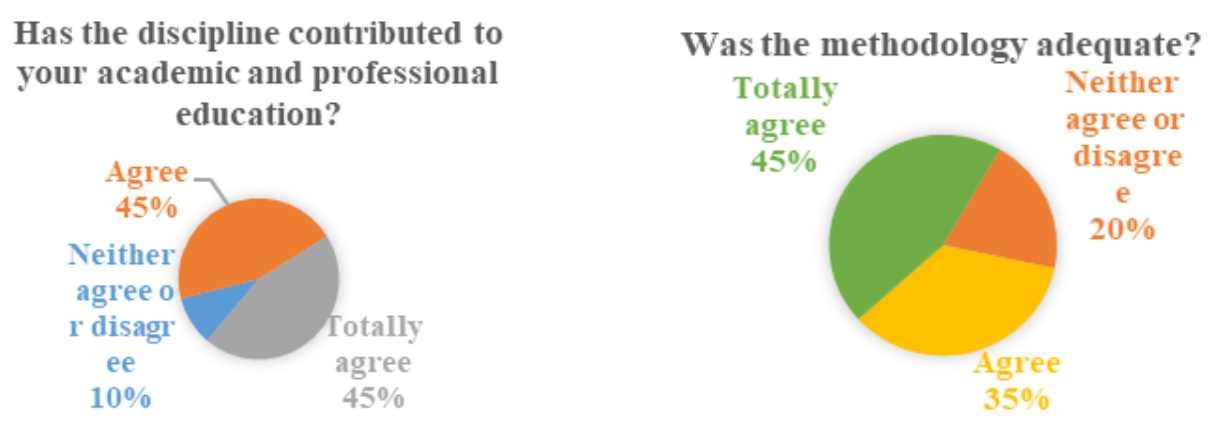

Fig. 9. Evaluation of methodology and contributions of the discipline.

\section{Threats to Validity}

The results obtained in this evaluation should be interpreted with caution because some problems occurred during data collection and analysis. Internal Threat: the data collected by the survey may not reflect the actual profile of participants. In order to reduce this risk, the questionnaires were prepared and revised collectively, with a small number of questions, a simple language and instructions to participants about guarantee of anonymity and purpose of the research. External Threat: the interpersonal relationship between teacher and students can lead to responses with an emotive bias. However, it was explained in advance that the questionnaires would not be used in the evaluation and that the data would be collected anonymously. It was possible to observe that the answers did not show a tendency of central bias. Conclusion Threat: the sample size may compromise the generalizability of the results. The sample obtained for the evaluation of the methodology may be considered small because it only contains 20 records. Moreover, these results cannot be generalized once they represent the perceptions and experience of the participants involved in the analyzed context. In order to better evaluate the results, the applied methodology was evaluated in two consecutive classes with similar results.

\section{Conclusions}

This paper presented a qualitative evaluation of PBL towards applied health informatics teaching. The study was conducted in an undergraduate class of Applied Informatics to Health composed of 21 students in the age group from 18 to 25 years. It was proposed for them the development of $\mathrm{m}$-health applications. With an exploratory method, the research was instrumented by the application of two surveys and by the qualitative analysis of the projects developed by the students. The results obtained in this work reassure the findings of previous works presented by Santos [2019]. A positive change was made in the groups' configuration: by separating the participants into seven teams composed of three students. With smaller teams, we noticed it was easier to share tasks and everyone had to participate in the app development. This change reduced 
IX Congresso Brasileiro de Informática na Educação (CBIE 2020)

Anais do XXXI Simpósio Brasileiro de Informática na Educação (SBIE 2020)

communication issues and motivated the teamwork. Furthermore, the teacher could follow-up the projects properly.

The students actively participated in the project's development, choosing their interest topics to create the apps. The PBL method encouraged students to become actively involved in project development, which included physical and mental activities requiring decision making and in-depth research. Hence, they demonstrated initiative and proactivity to search contents to build their applications. Besides, the methodology has taken the students to a different role than they are accustomed, moving them from the role of consumers to developers. According to the self-assessment, the students thought PBL was an adequate (81\%) and motivating $(68.5 \%)$ method towards the course. Among the 20 students that finished the course, 15 self-assessed as apt for app development and $65 \%$ of them expressed interest in continuing to develop applications.

When comparing the results presented by the previous class [Santos 2018, Santos 2019], a positive evolution was observed. A comparison of the results obtained in conducting surveys between the two groups allowed to identify similar results. In both classes, participants reported being heavy mobile users, having a little computer and programming knowledge. Most students from both classes also stated being motivated by the methodology employed, and they considered themselves able to continue developing applications after the course. Some students expressed interest in improving their projects and sharing results. A team from previous class improved their app and performed a user evaluation experiment [Matos 2019]. Another team performed a systematic mapping and evaluation of applications aimed at patients with depression and anxiety [Querino 2020].

With these findings, it is reasonable to suppose that the methodology has showed positive results. However, further evaluation studies may be conducted in order to confirm the results.

\section{References}

Barron, B. J., Schwartz, D. L., Vye, N. J., Moore, A., Petrosino, A., Zech, L., \& Bransford, J. D. (1998). Doing with understanding: Lessons from research on problem-and project-based learning. Journal of the learning sciences, 7(3-4), 271311.

Bilgin, I., Karakuyu, Y., \& Ay, Y. (2015). The effects of project based learning on undergraduate students' achievement and self-efficacy beliefs towards science teaching. Eurasia Journal of Mathematics, Science \& Technology Education, 11(3), 469-477.

de Campos, A., Machado, G. B., Rados, G. J. V., \& Todesco, J. L. (2016). Aprendizagem Baseada em Projetos: uma experiência em sala de aula para compartilhamento e criação do conhecimento no processo de desenvolvimento de projetos de software. Revista Competência, 9(2), 17-35.

Cardoso, J. P., Rosa, V. A., Lopes, C. R. S., Vilela, A. B. A., Santana, A. S. D., \& Silva, S. T. D. (2008). Construção de uma práxis educativa em informática na saúde para ensino de graduação. Ciência \& Saúde Coletiva, 13, 283-288. 
IX Congresso Brasileiro de Informática na Educação (CBIE 2020)

Anais do XXXI Simpósio Brasileiro de Informática na Educação (SBIE 2020)

Finocchio Júnior, José. Project Model Canvas: gerenciamento de projetos sem burocracia. (2013). Elsevier Brasil.

Helle, L., Tynjälä, P., \& Olkinuora, E. (2006). Project-based learning in post-secondary education - theory, practice and rubber sling shots. Higher Education, 51, 287-314

Kokotsaki, D., Menzies, V., \& Wiggins, A. (2016). Project-based learning: A review of the literature. Improving schools, 19(3), 267-277.

Mitre, S. M., Siqueira-Batista, R., Girardi-de-Mendonça, J. M., Morais-Pinto, N. M. D., Meirelles, C. D. A. B., Pinto-Porto, C., ... \& Hoffmann, L. M. A. (2008). Metodologias ativas de ensino-aprendizagem na formação profissional em saúde: debates atuais. Ciência \& saúde coletiva, 13, 2133-2144.

Masson, T. J., Miranda, L. F., Munhoz Jr, A. H., \& Castanheira, A. M. P. (2012). Metodologia de ensino: aprendizagem baseada em projetos (pbl). In Anais do XL Congresso Brasileiro de Educação em Engenharia (COBENGE), Belém, PA, Brasil (p. 13). sn.

Santos, L.C.; Neves, D.F.; Moura Filho, H. C.; Menezes, F. S. (2019) Aprendizagem baseada em projetos na informática em saúde: desenvolvendo aplicativos com App Inventor. RENOTE-Revista Novas Tecnologias na Educação, v. 17, n. 1, p. 42-51.

Pereira, S., Capelli, J. C. S., Abrahão, A. L., \& Anastacio, A. (2017). A experiência do uso da aprendizagem baseada em projetos como metodologia ativa no programa de educação pelo trabalho para a saúde na aprendizagem da prática profissional. DEMETRA: Alimentação, Nutrição \& Saúde, 12(4), 881-898.

Querino, J. de J.; Andrade, N. N; Santos, L.C. (2020). Levantamento e avaliação de aplicativos sobre ansiedade e depressão disponíveis em língua portuguesa. Revista de Saúde Digital e Tecnologias Educacionais.

Santos, M.A.; Guimarães, M.P.; A.B.E., K.C. (2017). O Ensino da Disciplina de Informática em Saúde nos Cursos de Graduação em Enfermagem. Em Rede-Revista de Educação a Distância, v. 4, n. 1, p. 166-173.

Santos, L. C; Neves, D. F.; de Moura Filho, H. C.; dos Santos Menezes, F.; da Silva, L. F. S. (2018). Prototipação de Aplicativos como Método de Aprendizagem na Informática em Saúde: Um Relato de Experiência. In: Anais do Workshop de Informática na Escola. p. 90.

Matos, L. F. A.; Costa, A. R.; de Oliveira Siqueira, G.; dos Santos Menezes, J. A.; Neves, D. F.; Santos, L. C. (2019). LabMorfoQuiz: um Aplicativo Gamificado como Recurso para Aprendizagem em Cursos Superiores de Saúde. RENOTE-Revista Novas Tecnologias na Educação, 17(3), 142-151.

Wolber, D., Abelson, H., Friedman, M. (2014). Democratizing computing with App Inventor. Get Mobile, 18(4), 53-58. 